\title{
Effects of Three Commonly Used Pharmaceutical products on Biochemical parameters of the Micro-alga Pseudokirchneriella subcapitata (Under Laboratory Conditions)
}

\author{
Jelan Mofeed \\ Aquatic Environment Department, Faculty of Fish Resources, Suez University, Egypt
}

\begin{abstract}
Despite the great importance of pharmaceutical products in our daily life, they have negative effects on the environment; where it may threatens many non-target organisms. The present study provides an integrated framework of contribution to understanding the toxicity of three commonly used pharmaceutical products (amoxicillin, naproxen and tramadol) on the micro-green alga Pseudokirchneriella subcapitata. The impact of pharmaceutical pollution on aquatic organisms can be evaluated by assessing its physiological response. The alga was exposed to sub-lethal concentrations $\left(\mathrm{LC}_{10}, \mathrm{LC}_{25}\right.$ and $\left.\mathrm{LC}_{50}\right)$ of each tested pharmaceutical to determine its impact on growth behavior, pigments, total lipids, protein and carbohydrate contents. The obtained results clarified that, exposure to the pharmaceuticals by their sub-lethal concentrations mostly resulted in a decrease in cell density up to $66.25 \%$ by amoxicillin and $37.24 \%$ by tramadol within $\mathrm{LC}_{50}$, although exposure to low naproxen concentration promoted cell density (up to $21.7 \%$ ) after $24 \mathrm{~h}$. Amoxicillin $(67.74-97.44 \%)$ followed by tramadol (59.67- 93.55\%) significantly reduced the content of the pigment after $96 \mathrm{~h}$ but in a different manner, however except within $\mathrm{LC}_{50}$, naproxen induced both carotenoids (4.55$11.61 \%)$ and chlorophyll-a $(1.54-9.23 \%)$ during the first $24 \mathrm{~h}$. The tested pharmaceuticals also reducing protein, carbohydrates and total lipid content of P.subcapitata at the end of the experiment by ratios up to 96.7, 86.2 and $74.9 \%$ respectively. Due to the dramatic effects of pharmaceuticals on the aquatic non-target organisms all new pharmaceutical products must undergo an environmental risk assessment test during and after the development of the product to obtain marketing approval.

Keywords: Pharmaceuticals, P.subcapitata, protein, lipid, carbohydrates, pigments.
\end{abstract}

\section{INTRODUCTION}

Recently and in a striking way, the world market is packed with an infinite number of pharmaceutical products, including hormones, analgesics, antibiotics, antidepressants, antihistamines, stimulants, antiinflammatory and various antiseptics additives, which designed to produce therapeutic effects in order to improve the life quality for both humans and animals (Gottschall et al., 2012; Miazek and Brozek-Pluska, 2019). Consequently, a considerable amount of these products seep through sewage systems due to the nonefficient removal by wastewater treatment, besides the contribution of the non-consumed drugs that disposed of in erroneous ways by pharmaceutical manufacturers (Daughton and Ruhoy, 2009; Zhang et al., 2019), which eventually reach the aquatic environment. In addition, the antibiotics and growth promoters that inserted in the feeding operations of large animals (Kummerer, 2009), also causing an increase in the concentration of some pharmaceutical active compounds in the aquatic environment on a global scale (Kosma et al., 2017). Worthwhile, the therapeutic groups of the pharmaceuticals products reached the aquatic environment are mostly active even in low concentrations range (pico-nmol. ${ }^{-1}$ ). Previous researchers detected the important differences between pesticides and pharmaceutical products (Relyea and Hoverman, 2006; Mosleh and Mofeed, 2014; Mosleh et al., 2014a), where pesticides used only if there is observed pest outbreaks during the growing season (Mosleh et al., 2005; Mosleh et al., 2014b), contrariwise, with increasing the global population, pharmaceutical products enter the aquatic environment incessantly and with large quantities.

Pharmaceutical products even at low concentrations have potential adverse effects on aquatic living organisms (Daughton and Ternes, 1999). Some pharmaceuticals such as ibuprofen, amoxicillin, mefenamic acid, oxytetracycline, and paracetamol were detected in water at levels that are not negligible for aquatic organisms (Isidori et al., 2005). However, until now there are no suffice strategies for environmental risk assessment of pharmaceuticals in order to protect aquatic organisms. Each compound of pharmaceuticals designed to do special functions in the cell; hence they can interact with specific receptors in the biochemical pathways (Tarfiei et al., 2018). Many of these pathways and receptors in the target cell be similar to that in the non-target aquatic organisms, therefore harmful effects could be expected (Boxall, 2004), especially where most pharmaceutical compounds resist any change in its chemical structure and it remains stable and active after being released into the environment (Kolpin et al., 2004; Bound and Voulvoulis, 2004). Therefore, pharmaceuticals can affect non-targeted organisms in the aquatic environment even by its low concentrations.

The widely distributed microalgae are the primary food supplier in the aquatic ecosystem, representing the first step of the food chain (Lai et al., 2009; Mosleh and Mofeed, 2014), hence any threat affecting them will be reflected on the other aquatic organisms of the higher trophic levels and by extension, the human being. Many researchers recommended microalgae as sensitive bioindicators, for both long and short-term 
monitoring for ecotoxicological assessments of the aquatic ecosystem because the nonlinear responses of biological communities can reflect any environmental disturbances (Guo et al., 2015). Therefore, aquatic microalgae considered as a good pointer for aquatic monitoring programs to track any changes in water quality, hence it can follow up the impacts of the inserted pharmaceutical pollutants on the aquatic organisms, even with low concentrations, by evaluating the biochemical responses of the algal cells (Zhang et al., 2019).

Three pharmaceutical compounds belonging to the most consumed products in daily life were selected, namely amoxicillin (antibiotic), tramadol (analgesic) and naproxen (anti-inflammatory). The broad-spectrum antibiotic; amoxicillin is effective against both gramnegative and gram-positive bacteria, where it has a high absorption rate (Miazek and Brozek-Pluska, 2019). Due to its pharmacological properties, it is widely used not only in human treatments but also in veterinary medicine for curing and prevention of skin, urinary and gastrointestinal bacterial infections (Isidori et al., 2005). While in 1976 naproxen was approved for medicinal use, where it belongs to one of the most important worldwide pharmaceutical groups and identified as a nonsteroidal anti-inflammatory and antipyretic drug, hence it can be widely used in the treatment of numerous widespread diseases, such as rheumatoid arthritis and other rheumatic, beside musculoskeletal disorders, menstrual cramps, acute gout, and fever (Daughton and Ruhoy, 2009). Tramadol, which used to moderately severe pain, is available as a generic medication with many trade names and it is generally safe at recommended doses but higher doses may lead to toxicity. Generally, pharmaceutical compounds have detrimental hassled unavoidable effects on aquatic microbial communities and hence on the whole aquatic ecosystem, which consequently negatively influence human health (Gottschall et al., 2012). Therefore, the overall aim of this study was to contribute in the understanding the toxicity of the three commonly used pharmaceutical products (amoxicillin, naproxen and tramadol) on the micro-green alga, Pseudokirchneriella subcapitata, to investigate how those products impact on its growth beside its influence on the production of protein, carbohydrate, total lipid, as well as carotenoids and chlorophyll which would basically, upgrade our information about the expected modern environmental hazard on the aquatic ecosystems and develop a strategy to control it.

\section{MATERIALS AND METHOD}

\section{Tested pharmaceutical compounds}

The three pharmaceutical compounds (tramadol, naproxen, and amoxicillin) used in this study with purity $\geq 99 \%$ (Sigma). The stock solutions of the three pharmaceutical products were prepared using deionized water and stock solutions were sterile-filtered using glass filter paper and stored in the dark at $5{ }^{\circ} \mathrm{C}$ until used (Table 1).

Table (1): Chemical structure and drug class of the tested pharmaceuticals.

\begin{tabular}{llll}
\hline \hline Tested Pharmaceuticals & Drug CLASS & Molecular Formula & Chemical Structure Depiction \\
\hline Amoxicillin & Antibiotic & $\mathrm{C}_{16} \mathrm{H}_{19} \mathrm{~N}_{3} \mathrm{O}_{5} \mathrm{~S}$ & \\
Naproxen & Anti-inflammatory & $\mathrm{C}_{14} \mathrm{H}_{13} \mathrm{NaO}_{3}$ & $\mathrm{C}_{16} \mathrm{H}_{25} \mathrm{NO}_{2}$ \\
Tramadol & Analgesic & & \\
\hline \hline
\end{tabular}

\section{Algal strain and culture medium}

The unicellular green alga Pseudokirchneriella subcapitata (Korshikov) F. Hinda, which formerly named Selenastrum capricornutum Printz, was obtained from Microbiology Lab of Faculty of Fish Resources, Suez University, Egypt. The unicellular green alga $P$. subcapitata strain has been maintained under the laboratory conditions using the OECD growth medium, at $23 \pm 1^{\circ} \mathrm{C}$ and under continuous illumination $\left(60-80 \mu \mathrm{mol} . \mathrm{m}^{-2} \mathrm{~S}^{-1}\right)$ provided by white fluorescent lamps (Fora 50W) with continuous aeration and shaking (by orbital shaker, $130 \mathrm{rpm}$ ). P. subcapitata cells were harvested during their exponential growth phase and treated with different concentrations of the three pharmaceuticals.
Quantification of the pharmaceuticals residues After incubation of $P$. subcapiotata with the pharmaceuticals, an aliquot $(10 \mathrm{ml})$ media of each concentration was collected and then directly analyzed by high-performance liquid chromatography (HPLC), using a reversed phase column (Kromasil, C18, $100 \mathrm{~A}$, $5 \mathrm{~mm}, 250 \mathrm{~mm}, 3 \mathrm{~mm}$, CIL-Cluzeau). The pharmacyeuticals were eluted isocratically using methanol and water solvent $(35: 65 \%)$ for amoxicillin, methanol: acetonitrile: water and triethylamine (20:28: 52\%) for naproxen or orthophosphoric acid, trieth-ylamine, acetonitrile and methanol in a complex gradi-ent mode for tramadol. The UV absorbance 273, 270 and $340 \mathrm{~nm}$ for amoxicillin, naproxen, and tramadol, respectively, with a Diodearray detector their concentrations were detected (Javier et al., 2009). 
The rate of recovery was detected by the addition of 1 $\mathrm{ml}$ methanol containing $1 \mathrm{mg} \mathrm{ml}^{-1}$ pure of three pharmaceuticals compounds (Olarinmoye et al., 2016). The extraction of three pharmaceuticals compounds were carried out as described above and the average rate recovery was $92.874,90.58$ and $93.35 \%$ based on three replicates for amoxicillin, tramadol and naproxen respectively.

\section{Determination of sub-lethal concentrations}

The tests were conducted to determine the sub-lethal concentrations $\left(\mathrm{LC}_{10}, \mathrm{LC}_{25}\right.$ and $\left.\mathrm{LC}_{50}\right)$ of the tested pharmaceutical compounds against $P$. subcapitata by using different concentrations of the tested pharmaceutical compounds $(0.1,0.4,0.8,1.6,3.2,6.4,12.8$ and $25 \mathrm{mg} . \mathrm{L}^{-1}$ ) after 24,48 and 96 hours in $100 \mathrm{ml}$ conical flasks. Three replicates without amoxicillin, tramadol and naproxen were used as control. The $\mathrm{LC}_{10}, \mathrm{LC}_{25}$ and $\mathrm{LC}_{50}$ values were determined graphically according to Finney (1971).

\section{Determination of algal growth}

After different time of exposure to the sub-lethal concentrations $\left(\mathrm{LC}_{10}, \mathrm{LC}_{25}\right.$ and $\left.\mathrm{LC}_{50}\right)$ the growth of $P$. subcapitata was determined as cell number by using Rafter Counting Chamber.

\section{Estimation of carotenoids and chlorophyll a\&b}

By treating $P$. subcapitata with the sub-lethal concentrations of each pharmaceutical compounds and extraction by using acetone $(80 \%)$ after different

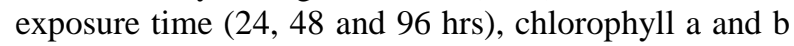
were determined according to Wellburn (1994), meanwhile the total Carotenoids were calculated according to Holm (1954).

\section{Determination of total lipid}

Lipid was extracted and quantified from freezedried algal biomass according to Lewis et al., (2000) during the entire period of the experiment.

\section{Determination of protein content}

With the sub-lethal concentrations of the tested pharmaceutical compounds, Pseudokirchneriella subcapitata suspensions were incubated for 24, 48 and 96 hrs in $20 \mathrm{ml}$ of medium supplied; under the conditions described previously, then after algal collection, the extracts were analyzed for protein determination according to Bradford method (Bradford, 1976).

\section{Determination of carbohydrate}

After incubation of P.subcapitata with the sublethal concentrations of pharmaceuticals for 24, 48 and $96 \mathrm{hrs}$, the cultures were centrifuged at $2000 \mathrm{xg}$ for 5 min. Then, $100 \mathrm{mg}$ of algal pellets were used for quantification of carbohydrate content as described by Dubois et al., (1956).

\section{Statistical analysis}

All the recorded data were determined from the triplicates and the results are expressed as a mean \pm standard deviation (SD). All statistical analyses were performed with Sigma Stat 2.03 (SSCP Inc.) for Windows.

\section{RESULTS}

\section{Sub-lethal concentrations of each pharmaceutical product}

The response of P.subcapitata to all concentration of the tested pharmaceuticals over the exposure time (24, 48 and $96 \mathrm{hrs}$ ), based on the $\mathrm{LC}_{10}, \mathrm{LC}_{25}$ and $\mathrm{LC}_{50}$ values clarified that naproxen was the least toxic compound, while regardless of response variable or exposure duration, amoxicillin was the most toxic compound (Table 2). The influence of tramadol on $P$. subcapitata revealed, $\mathrm{LC}_{50}$ value is $2.34 \pm 0.09 \mathrm{mg} . \mathrm{L}^{-1}$ after $96 \mathrm{hrs}$ of exposure. Meanwhile $\mathrm{LC}_{50}$ value for amoxicillin gave $0.35 \pm 0.01,0.38 \pm 0.02$ and $0.47 \pm 0.02$ mg. $\mathrm{L}^{-1}$ after 24,48 and $96 \mathrm{hrs}$, respectively.

\section{Residues of pharmaceutical products in both algal biomass and medium}

Residues of naproxen, amoxicillin and tramadol were quantified in both medium and $P$. subcapitata cells (Table 3 ) by using the HPLC. The present study revealed that amoxicillin is the most frequently detected pharmaceuticals in $P$. subcapitata within $\mathrm{LC}_{50}$, with residue fluctuated between $0.08 \pm 0.01$ to $0.16 \pm 0.01 \mu \mathrm{g} . \mathrm{g}^{-1}$, followed by the tramadol, which ranged between $0.14 \pm 0.02$ and $0.35 \pm 0.0 .1 \mu \mathrm{g} \mathrm{g} \mathrm{g}^{-1}$. The naproxen was also detected in $P$. subcapitata samples at residue levels from $0.22 \pm 0.03$ to $0.42 \pm 0.10 \mu \mathrm{g} . \mathrm{g}^{-1}$.

The residues of the three pharmaceutical products were also detected in the media after different time of exposure. The pharmaceuticals residues in the media showed a relative decrease during the interred period of investigation. Indeed, after 2 days with the lowest initial concentration, $57.1 \%$ of the amoxicillin remained in the media, while after 4 days of exposure the residues of amoxicillin were 43.11, 49.38 and $57.1 \%$ of initial concentrations for $\mathrm{LC}_{10}, \mathrm{LC}_{25}$ and $\mathrm{LC}_{50}$ respectively.

\section{Influence of pharmaceuticals on the growth}

The addition of the tested pharmaceuticals by its sub-lethal concentrations ( $\mathrm{LC}_{10}, \mathrm{LC}_{25}$ and $\mathrm{LC}_{50}$ ), mostly resulted in a decrease in cell density of $P$. subcapitata, although the apparent disparity in responses to each product. A glance on figure (1-a, b and c) revealed that, the maximum growth suppressions during the entire period of investigation was recorded with the antibiotic amoxicillin, giving its maximum inhibition within $\mathrm{LC}_{50}$ after $96 \mathrm{hrs}\left(0.54 \times 10^{6} \mathrm{cell}^{\mathrm{m}} \mathrm{m}^{-1}\right)$ when compared to the control which reached $6.31 \times 10^{6}$ cell. $\mathrm{ml}^{-1}$ at the same time. Although tramadol also reduced cell density, it has less influence than amoxicillin, where it gave $1.82 \times 10^{6}$ cell. $\mathrm{ml}^{-1}$ within the high concentration at the end of the experiment. Inspection of figure (1) reflects the less influence of naproxen on cell density of $P$. subcapitata during the investigation period. Paradoxically, it is worth mentioning that, exposure to low naproxen concentrations $\left(\mathrm{LC}_{10}\right.$ and $\mathrm{LC}_{25}$ ) promoted the cell density over the control during the first $48 \mathrm{~h}$. However, at the end of the experiment (after $96 \mathrm{hrs}$ ), all treatments showed growth inhibition trend. 
Table (2): Toxicity of three pharmaceutical products $\left(\mathrm{mg}^{\mathrm{L}} \mathrm{L}^{-1}\right)$ on Pseudokirchneriella subcapitata after 24, 48 and $96 \mathrm{~h}$ of exposure.

\begin{tabular}{|c|c|c|c|c|}
\hline \multirow[t]{2}{*}{$\begin{array}{l}\text { Pharmaceutical } \\
\text { Compounds }\end{array}$} & \multirow[t]{2}{*}{$\begin{array}{l}\text { Time } \\
\text { (hr) }\end{array}$} & \multicolumn{3}{|c|}{ Toxicity $\left(\mathrm{mg} . \mathrm{L}^{-1}\right)^{*}$} \\
\hline & & $\mathbf{L C}_{10}$ & $\mathbf{L C}_{25}$ & $\mathbf{L C}_{50}$ \\
\hline \multirow{3}{*}{ Amoxicillin } & 24 & $1.67 \pm 0.08$ & $0.81 \pm 0.05$ & $0.35 \pm 0.01$ \\
\hline & 48 & $1.54 \pm 0.05$ & $0.93 \pm 0.02$ & $0.38 \pm 0.02$ \\
\hline & 96 & $1.67 \pm 0.03$ & $0.93 \pm 0.10$ & $0.47 \pm 0.02$ \\
\hline \multirow{3}{*}{ Tramadol } & 24 & $10.2 \pm 0.04$ & $6.03 \pm 0.95$ & $2.10 \pm 0.08$ \\
\hline & 48 & $9.6 \pm 0.12$ & $5.12 \pm 0.65$ & $2.02 \pm 0.05$ \\
\hline & 96 & $11.2 \pm 0.89$ & $6.51 \pm 0.69$ & $2.34 \pm 0.09$ \\
\hline \multirow{3}{*}{ Naproxen } & 24 & $25.01 \pm 1.25$ & $13.33 \pm 1.02$ & $4.85 \pm 0.08$ \\
\hline & 48 & $24.30 \pm 1.35$ & $13.21 \pm 0.95$ & $4.61 \pm 0.06$ \\
\hline & 96 & $26.22 \pm 1.85$ & $14.61 \pm 0.101$ & $5.99 \pm 0.54$ \\
\hline
\end{tabular}
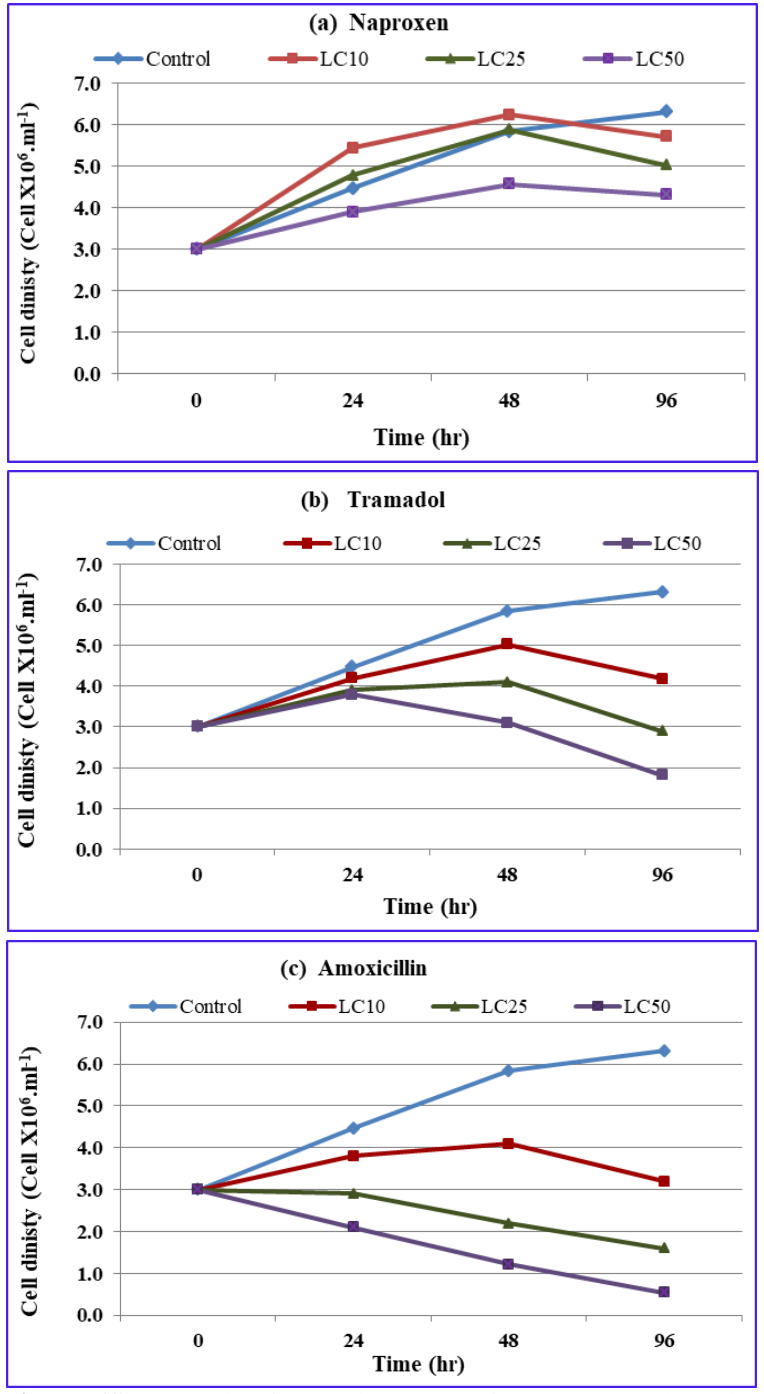

Figure (1): Growth of $P$. subcapitata after 24, 48 and 96 hrs exposure to (a) Naproxen, (b) Tramadol and (c) Amoxicillin.

\section{Impact of pharmaceuticals on pigments content}

The result illustrated in figure (2- a, b and c) clarify that, the tested pharmaceuticals had more or less the same trend of influence on the $P$. subcapitata pigments (chlorophyll a, chlorophyll b and carotenoids). Among those pigments, amoxicillin followed by tramadol significantly reduced the pigment content along the period of the experiment but in a different manner. It is noticeable that, the decline in pigment content increased with concentration. The data pertaining to naproxen clarified that except within $\mathrm{LC}_{50}$, naproxen induced both carotenoids and chlorophyll content during the first 48 h. However, it tended to reduce all pigments content during the rest of the experiment but with less effect than amoxicillin and tramadol (Figure 2).

\section{Impact of pharmaceuticals on protein, lipid and carbohydrate contents}

The recorded results showed that, the three tested pharmaceuticals (amoxicillin, tramadol and naproxen) significantly reduce protein content after 48 and $96 \mathrm{~h}$; while a slight inhibition effect was recorded after the first $24 \mathrm{~h}$. It is of interest to mention that, the amoxicillin dramatically inhibit protein production within all concentrations during the period of investigation, giving its maximum $(96.7 \%)$ within $\mathrm{LC}_{50}$ after $96 \mathrm{~h}$ (Figure 3). As it was illustrated in figure 4, total carbohydrates suffer from the same inhibition trend. It is worth to mention that, the lowest inhibition of carbohydrate production by $P$. subcapitata was by tramadol, where its inhibition ranged between $17.4 \%$ and $57.9 \%$, obtaining the maximum inhibition within $\mathrm{LC}_{50}$ after $96 \mathrm{~h}$ (Fig. 4). Contrarily, amoxicillin was responsible for the maximum reduction in carbohydrate production with concentration and time (from 30 to $86.2 \%)$. 
Concerning lipid, control of $P$. subcapitata showed stable total lipid content during the $96 \mathrm{hrs}$ of the experiment (Figure 5). Total lipid content with amoxicillin and tramadol exhibited the same trend of decrease depending on both the concentration and the time of exposure, where it shows the maximum decrease when alga exposed to the $\mathrm{LC}_{50}$ of amoxicillin for 24, 48 and $96 \mathrm{hrs}$ (51.6, 59.1 and 74.9\%). Meanwhile, naproxen enhanced total lipid productivity by $6.1,14.1$ and $4.7 \%$ within $\mathrm{LC}_{10}, \mathrm{LC}_{25}$ and $\mathrm{LC}_{50}$ respectively after the first $24 \mathrm{hrs}$ and only by $3 \%$ after 48 within $\mathrm{LC}_{10}$.

Table (3): Residues of Amoxicillin, Tramadol and Naproxen in the medium and in P.subcapitata after 24, 48 and $96 \mathrm{~h}$ of exposure.

\begin{tabular}{|c|c|c|c|c|c|c|c|}
\hline \multirow[t]{2}{*}{$\begin{array}{l}\text { Pharmaceutical } \\
\text { Compounds }\end{array}$} & \multirow{2}{*}{$\begin{array}{c}\text { Initial } \\
\left.\text { conc.(mg. } \mathrm{L}^{-1}\right)\end{array}$} & \multicolumn{3}{|c|}{ Residues $\left(\mathrm{mg.L^{-1 }}\right)$ in medium/hr* } & \multicolumn{3}{|c|}{ Residues $\left(\mu \mathrm{g} . \mathrm{g}^{-1}\right)$ in algae/hr* } \\
\hline & & 24 & 48 & 96 & 24 & 48 & 96 \\
\hline \multirow{4}{*}{ Amoxicillin } & $\mathrm{LC}_{10}(\mathbf{1 . 6 7})$ & $1.52 \pm 0.12$ & $1.32 \pm 0.23$ & $0.95 \pm 0.05$ & $0.42 \pm 0.10$ & $0.54 \pm 0.24$ & $0.65 \pm 0.023$ \\
\hline & $\mathrm{LC}_{25}(\mathbf{0 . 8 1})$ & $0.75 \pm 0.21$ & $0.62 \pm 0.09$ & $0.41 \pm 0.04$ & $0.21 \pm 0.05$ & $0.28 \pm 0.01$ & $0.38 \pm 0.012$ \\
\hline & $\mathrm{LC}_{50}(\mathbf{0 . 3 5})$ & $0.33 \pm 0.01$ & $0.20 \pm 0.02$ & $0.16 \pm 0.05$ & $0.08 \pm 0.01$ & $0.12 \pm 0.03$ & $0.16 \pm 0.01$ \\
\hline & $\mathrm{LC}_{10}(\mathbf{1 0 . 2 0})$ & $9.25 \pm 0.5$ & $8.60 \pm 0.24$ & $5.36 \pm 0.21$ & $3.65 \pm 0.08$ & $4.58 \pm 0.3$ & $5.01 \pm 0.021$ \\
\hline \multirow[t]{3}{*}{ Tramadol } & $\mathrm{LC}_{25}(\mathbf{6 . 0 3})$ & $5.65 \pm 0.41$ & $4.23 \pm 0.21$ & $3.1 \pm 0.25$ & $2.56 \pm 0.25$ & $2.95 \pm 0.14$ & $3.12 \pm 0.14$ \\
\hline & $\mathrm{LC}_{50}(\mathbf{2 . 1 0})$ & $2.01 \pm 0.02$ & $1.45 \pm 0.03$ & $0.95 \pm 0.06$ & $0.14 \pm 0.02$ & $0.20 \pm 0.01$ & $0.35 \pm 0.01$ \\
\hline & $\mathrm{LC}_{10}(\mathbf{2 5 . 0 1})$ & $23.23 \pm 1.59$ & $19.1 \pm 0.92$ & $16.6 \pm 0.59$ & $6.05 \pm 0.56$ & $7.25 \pm 0.42$ & $9.25 \pm 0.54$ \\
\hline \multirow[t]{2}{*}{ Naproxen } & $\mathrm{LC}_{25}(\mathbf{1 3 . 3 3 )}$ & $12.6 \pm 1.05$ & $10.1 \pm 0.82$ & $8.35 \pm 0.25$ & $2.95 \pm 0.12$ & $3.25 \pm 0.09$ & $4.25 \pm 0.12$ \\
\hline & $\mathrm{LC}_{50}(\mathbf{4 . 8 5})$ & $4.85 \pm 0.06$ & $3.32 \pm 0.91$ & $2.01 \pm 0.10$ & $0.22 \pm 0.03$ & $0.26 \pm 0.01$ & $0.42 \pm 0.10$ \\
\hline
\end{tabular}

*Data presented are means \pm standard deviation.

\section{DISCUSSION}

Recently, it was noted that there are many pharmaceutical products reached water bodies due to receiving untreated or even insufficiently treated wastewater as a result of an increase in the consumption of these compounds in our daily life. The influence of three tested pharmaceuticals on the performance of $P$. subcapitata has been assessed by determining cell density, chlorophyll a, chlorophyll b, carotenoids, protein, lipid and carbohydrates contents. It is noticeable in the present study that, even by the sub-lethal concentrations of amoxicillin, tramadol and naproxen, regarded to be toxic or at least suppressor for $P$. subcapitata. The impacts of $\mathrm{LC}_{50}$ of the tested pharmaceuticals were compatible with those reported by using sulfamethoxazole, erythromycin and ciprofloxacin on microalgae and aquatic plants (Tang et al., 1997; Teisseire et al., 1999; Liu et al., 2011). The determined residues of amoxicillin, tramadol and naproxen in the media and algal biomass clarified that, the decrease in the concentration of pharmaceuticals in the media may be attributed to degradation, transmission, adsorption and absorption (Musleh et al., 2005; Mofeed and Mosleh, 2013; Mofeed and ElBilawy, 2020), but in our experiment, adsorption and transmission can be excluded since no sediments were present in the experimental system. Tramadol, amoxicillin and naproxen do not readily degrade (Mudgal et al., 2013), so the decrease in their concentration attributed to absorption by the algal cell, especially where it accompanied with increasing their residue in the algal biomass. However, the rat of decrease was slower with high concentrations than the lower, due to the toxic effects of the high concentrations on $P$. subcapitata.

The obtained results showed that, the exposure to the sub-lethal concentrations of each pharmaceutical can reduce the growth and pigment productivity of $P$. subcapitata, which indicates an inhibitory effect of those pharmacologically active compounds by disturbing the metabolic and photosynthetic activities. In this line, Olivier et al., (2003) reported that the chlorophenol and triclosan compounds can be accumulated in the green algae and have strong growth inhibitory effects, causing damage to the integrity of cell walls, interferes with fatty acid synthesis and cell division dysfunction. In another study on the green algae Raphidocelis subcapitata exposed to antineoplastic pharmaceuticals, Thrupp (2016) demonstrated growth inhibition and disturbance in its bioassay test. Moreover, Guo et al., (2015), indicated that some pharmaceuticals such as amphotericin, erythromycin, ciprofloxacin, and sulfamethoxazole inhibited the photosynthetic electron transport of the photosynthetic algae and caused disruption of cell growth. The result which agreed with the obtained result and also in accordance with Gentili and Fick (2017) who found that when algae exposed to $0.05 \mathrm{mg} . \mathrm{L}^{-1}$ metconazole, Chlorophyll a, Chlorophyll b, and total Chlorophyll contents decreased compared to the control by 16.5 , 22.4 and $40.4 \%$ respectively. These decreases attributed to the influence of the pharmaceuticals which induced hindrance in pigment biosynthetic pathway, besides the degradation in the existing pigment causing 

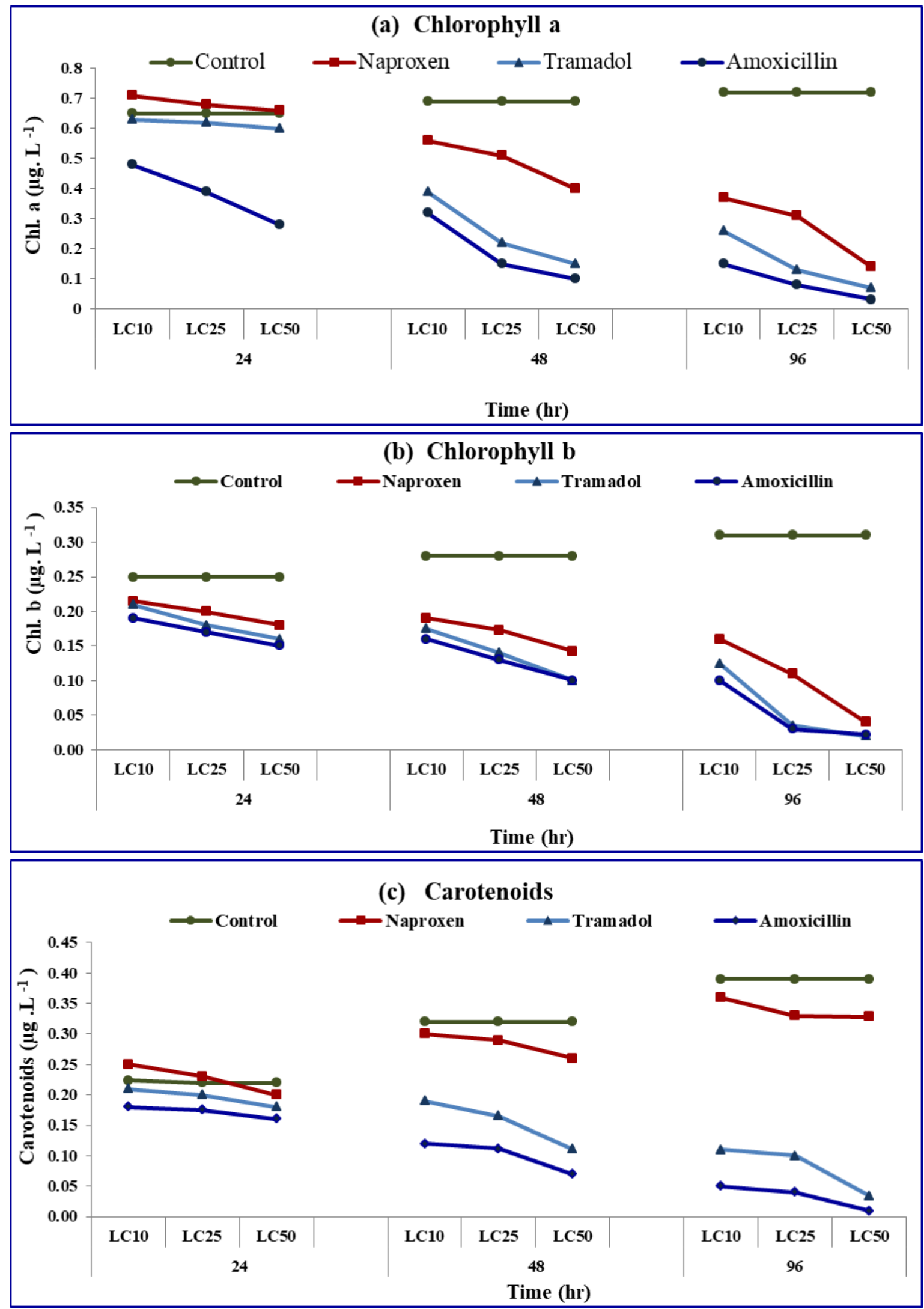

Figure (2): Effect of Naproxen, Tramadol, and Amoxicillin on (a) Chlorophyll a, (b) Chlorophyll b and (c) Carotenoids contents of $P$. subcapitata after 24,48 and 96 hrs of exposure. 


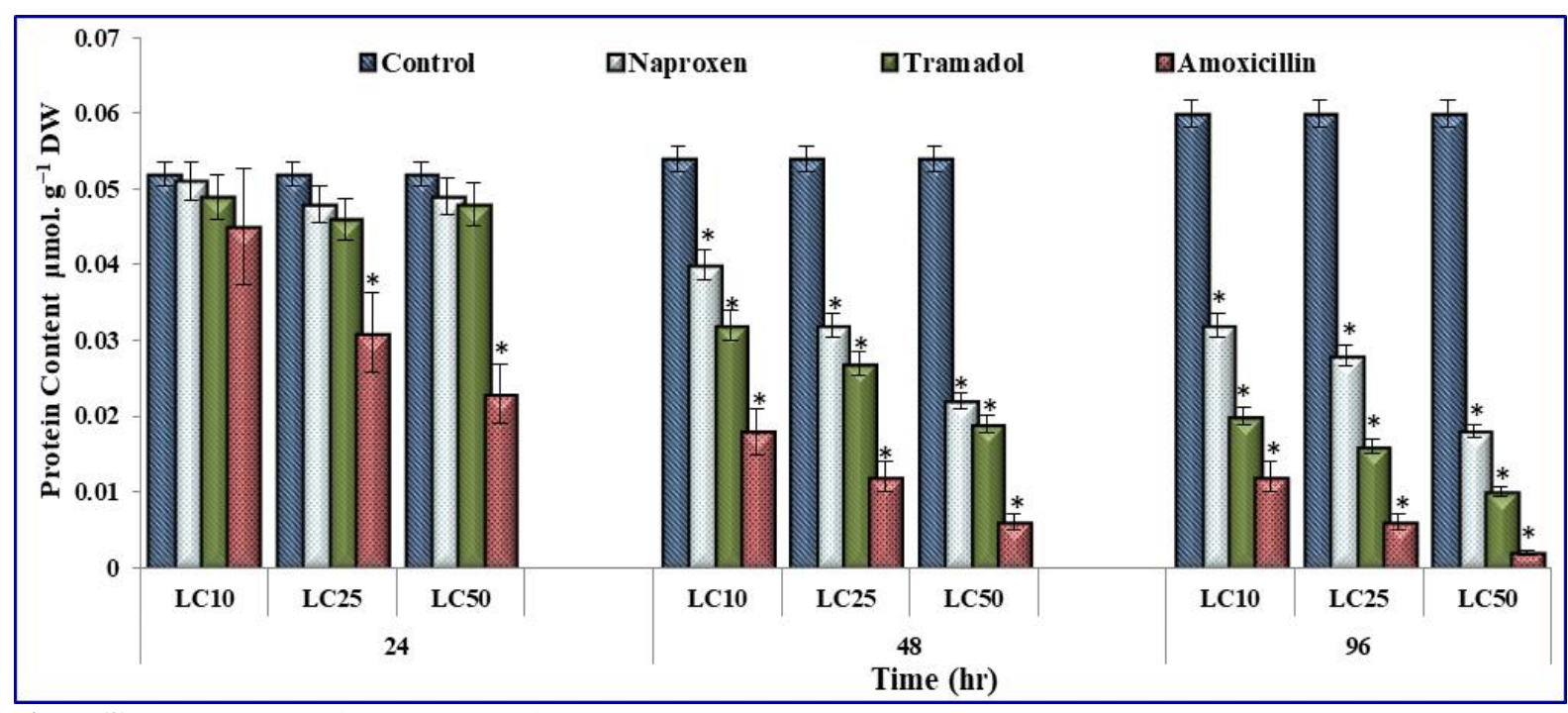

Figure (3): Protein content of $P$. subcapitata after 24, 48 and 96 hrs of exposure to Naproxen, Tramadol, and Amoxicillin.

*Significantly different at $P \leq 0.05$ in a Student Newman-Keuls test.

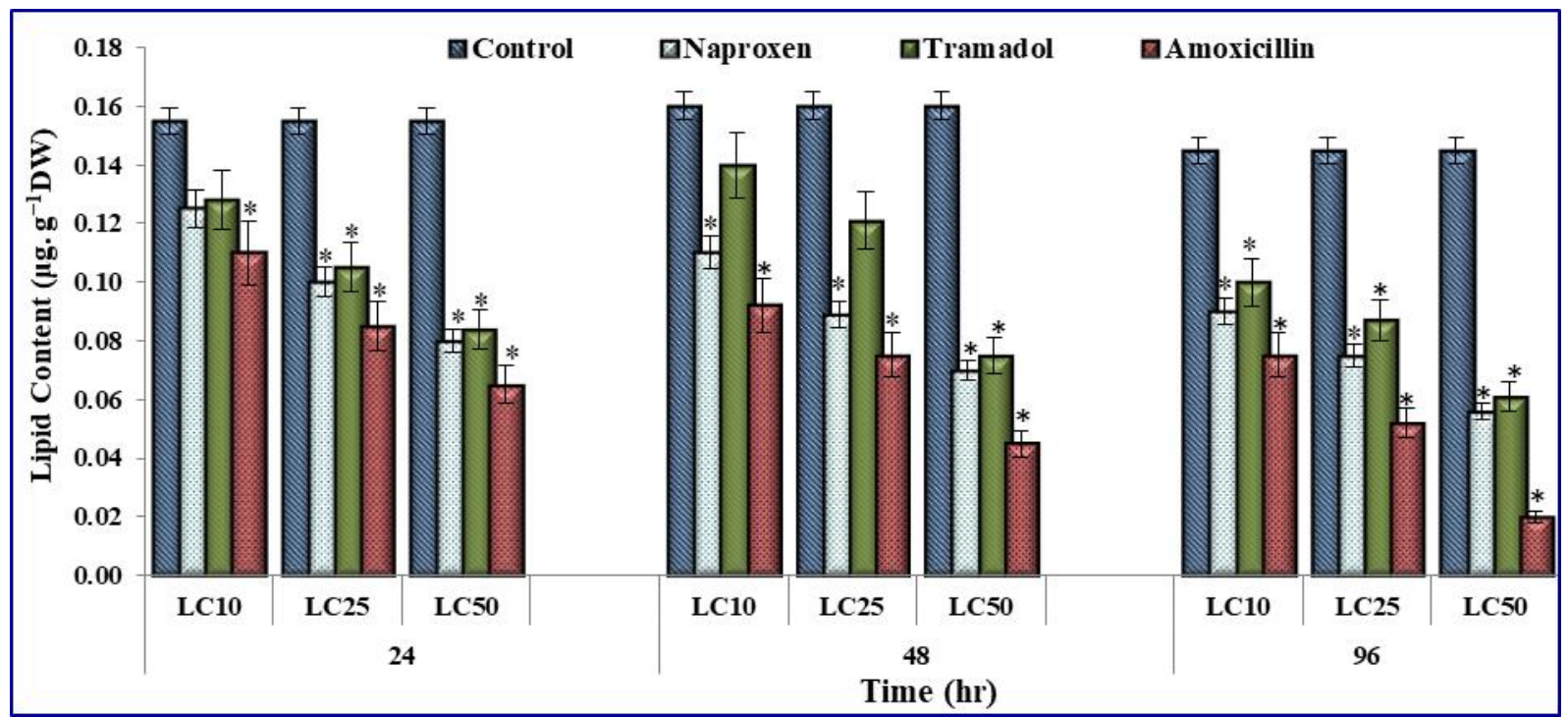

Figure (4): Carbohydrate content of P. subcapitata after 24, 48 and 96 hrs of exposure to Naproxen, Tramadol, and Amoxicillin.

*Significantly different at $P \leq 0.05$ in a Student Newman-Keuls test.

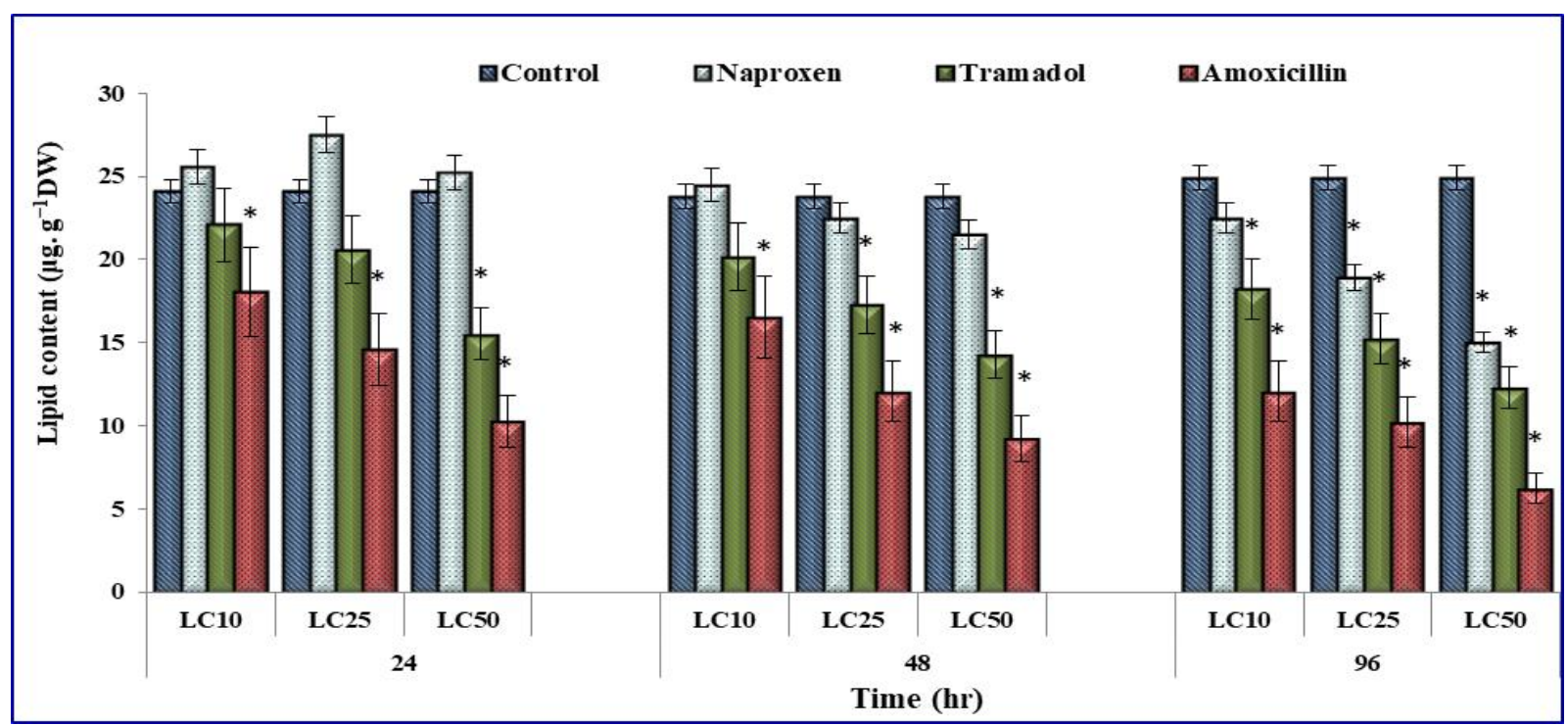

Figure (5): Total lipids content of P. subcapitata after 24, 48 and 96 hrs of exposure to Naproxen, Tramadol, and Amoxicillin. *Significantly different from control at $P \leq 0.05$ in a Student Newman-Keuls test. 
a reduction in photosynthesis capacity. In another study by Wong (2000), who demonstrated the influence of glyohosate on the algal growth, chlorophyll and carotenoids of Scenedesmus quadricauda, and explained that exposure to $0.78 \mu \mathrm{mol} . \mathrm{L}^{-1}$ of glyphosate lead to growth inhibited by $84.7 \%$, while chlorophyll suppressed by $65.7 \%$. In contrary, we found that during the first $48 \mathrm{hrs}$ of exposure to the low concentration of naproxen $\left(\mathrm{LC}_{10}\right)$, growth was promoted and the inhibition of cell growth increased with increasing naproxen concentrations. The increase in the beginning which followed by decrease with concentrations is an attempt by the cell to adapt with the used pharmaceuticals through establishing antioxidant and antitoxic strategies that failed with increasing concentrations.

Miazek and Brozek-Pluska (2019) reported that, exposure to pharmaceuticals and personal care products disturb enzymes and intracellular structure of the microalgal cells. The obtained results showed that, protein synthesis in $P$. subcapitata was dramatically reduced by the three tested pharmaceuticals (amoxicillin, tramadol and naproxen) after 48 and $96 \mathrm{hrs}$, however the slight suppression was recorded after $24 \mathrm{hrs}$, which indicates the toxicity of these compounds. While, the maximum inhibition, during the experimental period, was by amoxicillin within $\mathrm{LC}_{50}$ after $96 \mathrm{hrs}$. The phenomena which explained by Brain et al., (2008), who reported that, antibiotics can hinder the synthesis of protein by irreversibly binding to the subunits of ribosomes, which might disrupt transcription and translation (Sharma and Dubey, 2010). Unfortunately, the inspection of the literature shows that there is limited information about the influence of pharmaceutical compounds on lipids and carbohydrates in microalgae, which gives this study importance as one of the pioneer studies on this point. The obtained results elucidated that, naproxen, tramadol and amoxicillin inhibited both total lipid and carbohydrates production during the entire period of the experiment. However, the impact of tramadol on carbohydrate productivity by $P$. subcapitata, was lower than (17.4-57.9\%) amoxicillin, and naproxen. Amoxicillin was responsible for the maximum reduction $(30-86.2 \%)$ in lipids production with both concentration and time. Miazek and Brozek-Pluska (2019) indicated that, pharmaceutical products can discourage carbohydrates composition in the cells by disturbing the enzyme activity and inevitably the cell metabolism. In this connection, lipid content exhibited decrease with amoxicillin and tramadol depended on the concentration and the time of exposure, giving its maximum decrease when alga exposed to $\mathrm{LC}_{50}$ of the pharmaceuticals. Meanwhile, naproxen enhanced total lipid productivity (14.1-4.7\%) after the first $24 \mathrm{~h}$ and after 48 hrs $(3 \%)$ only within $\mathrm{LC}_{10}$, meanwhile, it declined with higher concentrations. The results which conformed with Zhang et al., (2019) who mentioned that, the detailed mechanisms about the impact of pharmaceuticals and industrial chemicals still unclear, where some of them had motivating impact on algae lipid accumulation within low concentrations, however higher concentrations inhibited the lipid production, and added that this inhibition could be due to the partially suppressing the relevant enzyme activities that led to blocking lipid synthesis.

\section{CONCLUSION}

Pharmaceutical products may have therapeutic benefits, but the uncontrolled increase in consumption does not only harm our bodies, but it negatively reflected on other nontarget organisms. The current study provides evidence on the toxic effect of three commonly used pharmaceutical products (amoxicillin, naproxen and tramadol) on microgreen alga Pseudokirchneriella subcapitata. Where the tested pharmaceuticals not only influenced both growth and photosynthetic pigments, but also cause decrease in its protein, carbohydrates and total lipid content. Therefore, competent authorities should prevent or at least reduce the access of pharmaceutical products to water bodies by using advanced effective sewage treatment. Besides, implementation of strict legislation for all new pharmaceutical products to undergo environmental risk assessment tests during and after the development of the product to obtain marketing approval. This is in addition to highlighting the need for indispensable extensive studies to give an obvious picture of the effect of these pharmaceutical products on aquatic organisms.

\section{REFERENCES}

BOUND, J.P AND N.VOULVOULIS. 2004. Pharmaceuticals in the aquatic environment-a comparison of risk assessment strategies. Chemosphere, 56(11):1143-55.

BOXALL, A.B., L.A. FOGG, P.A. BLACKWELL, P. KAY, E.J. PEMBERTON, A. CROXFORD. 2004. Veterinary medicines in the environment. Rev Environ ContamToxicol, 180:1-91.

BRADFORD, M. M, 1976. A rapid and sensitive method for the quantitation of microgram quantities of protein utilizing the principle of protein-dye binding. Anal Biochem,72:248-54 .

BRAIN, R. A., M. L. HANSON, K. R. SOLOMON, AND B. W. BROOKS. 2008. Aquatic plants exposed to pharmaceuticals: effects and risks. Reviews of Environmental Contamination and Toxicology, 192, 67-115.

DAUGHTON, C .G. AND T. A. TERNES.1999. Pharmaceuticals and personal care products in the environment: agents of subtle change. Environmental health perspectives, 13:588-594.

DAUGHTON, G. AND I.S. RUHOY. 2009. Environmental footprint of pharmaceuticals: The significance of factors beyond direct excretion to sewers. Environmental Chemistry, 12, 2495-2521.

DUBOIS, M., K.A.GILLES, J.K. HAMILTON AND P.A.REBERS. 1956. Colorimetric method for determination of sugars and related substances. Anal Chem., 28(3): 350-356

FINNEY, G. 1978.Probit Analysis, 3rd ed. By D. J. Finney, Cambridge University Press, 32 E. 57th St., New York.

GENTILI G. F. AND J. FICK. 2017. Algal cultivation in urban wastewater: an efficient way to reduce 
pharmaceutical pollutants. J ApplPhycol, 29(1): 255-262. GOTTSCHALL, N., E.TOPP, C. METCALFE, M. EDWARDS, M.PAYNE, S. KLEYWEGT, P.RUSSELL AND D.R. LAPEN. 2012. Pharmaceutical and personal care products in groundwater, subsurface drainage, soil, and wheat grain, following a high single application of municipal biosolids to a field. Chemosphere, 87(2):194203.

GUO, Y., A. BOXALL, AND K.SELBY. 2015. The design and construction of standard biological parts for metabolic engineering in Saccharomyces cerevisiae. Nucleic Acids Res, 43(13): 88.

HOLM, G. 1954.Chlorophyll mutations in barley. Acta Agric. Scand, 4, 457-471.

ISIDORI, M., L. LAVORGNA, N. ANGELA , P.LUIGIA AND P. ALFREDO. 2005. Toxic and genotoxic evaluation of six antibiotics on non-target organisms, Science of The Total Environment, 346: 87-98.

JAVIER F., J. BENITEZ, L. ACERO, F. J. REAL AND G. ROLDÁN. 2009. Ozonation of pharmaceutical compounds: Rate constants and elimination in various water matrices, Chemosphere, 1: 53-59.

KOLPIN, D.W., M. SKOPEC , M.T. MEYER, E.T. FURLONG AND S.D. ZAUGG. 2004. Urban contribution of pharmaceuticals and other organic wastewater contaminants to streams during differing flow conditions. Sci Total Environ. 26; (1-3):119-130.

KOSMA K. I., A.L.DIMITRA AND A.A TRIANTAFYLLOS. 2017. Investigation of PPCPs in wastewater treatment plants in Greece: Occurrence, removal and environmental risk assessment. Science of The Total Environment, 467, 421-438.

KUMMERER, K. 2009. The presence of pharm-aceuticals in the environment due to human use present knowledge and future challenges. Journal of Environmental Management, 2354-2366.

LAI, T.P., K.A. STAUFFER, A. MURTHI , H.H. SHAHEEN, G. PENG, N.C. MARTIN AND A.K. HOPPER. 2009. Mechanism and a peptide motif for targeting peripheral prot eins to the yeast inner nuclear membrane. Traffic, 10 (9):1243-56.

LEWIS, M.J., B.J. NICHOLS, C. PRESCIANOTTOBASCHONG, H. RIEZMAN, H.R. PELHAM. 2000. Specific retrieval of the exocytic SNARE Snc1p from early yeast, Molecular Biology of the Cell, 11, 1.

LIU, B., L. LARSSON, V. FRANSSENS, X. HAO, S.M. HILL, V. ANDERSSON, D. HÖGLUND, J. SONG, X. YANG, D. ÖLING. 2011. Segregation of protein aggregates involves actin and the polarity machinery. Cell 147(5):959-61.

MIAZEK, K. AND B.BROZEK-PLUSKA. 2019. Effect of PHRs and PCPs on Microalgal Growth, Metabolism and Microalgae-Based Bioremediation Processes: A Review. International journal of Molecular Scinces, 20, 2492.

MOFEED, J. AND E.H. EL-BILAWY. 2020. Toxicity and disruptive impacts of Fenhexamid fungicide against the green alga, Chlorella vulgaris. Egypt. Acad. J. Biolog. Sci., 12(1): 45-57.
MOFEED, J.AND Y. MOSLEH. 2013. Toxic responses and antioxidative enzymes activity of Scenedesmus obliquus exposed to fenhexamid and atrazine, alone and in mixture. Ecotoxicol Environ Saf., 95: 234-240.

MOSLEH, Y., AND J.MOFEED. 2014. Biochmical biomarkers in algae Scenedesmae obliquus exposed to heavy metals $\mathrm{Cd}, \mathrm{Cu}$ and $\mathrm{Zn}$. Life Science Journal 11(10): $994-1004$.

MOSLEH, Y., J. MOFEED, A. O. ALMAGRABI, T. MOUSA, AND M.S. NAIF AND M.KADASA. 2014b. Dietary intake of pesticides based on vegetable consumption: A case study, Jeddah, Kingdom of Saudi Arabia. Life Science Journal, 11: 680-688.

MOSLEH, Y., J.MOFEED, M.AFIFI, AND A.O. ALMAGHRABI. 2014a. Biological effects of pyrimethinal on aquatic worms (Tubifextubifex) under laboratory conditions. Bull Environ ContamToxicol, 92:85-89.

MOSLEH, Y., S. PARIS-PALACIOS, M.COUDERCHET, S.BIAGIANTI-RISBOURG AND G.VERNET. 2005. Metallothionein induction, antioxidative responses, glycogen and growth changes in Tubifextubifex (Oligochaete) exposed to the fungicide, fenhexamid. Environmental Pollution, 135: 73-82.

MUDGAL S., A. DE-TONI, S. LOCKWOOD, K. SALÈS, T. BACKHAUS. 2013. Study on the environmental risks of medicinal products.Bio. intelligence service, 1310 .

MUSLEH, S. M., R. YOUSSEF AND A. AMARO. 2005. Chemical and structural properties of modified Jordanian zeolite and its use for removal of heavy metals from aqueous solution. Ultra Sciences, 17(3):365-378.

OLARINMOYE, O., A.BAKARE, O.UGWUMBA AND A. HEIN. 2016. Quantification of pharmaceutical residues in wastewater impacted surface waters and sewage sludge from Lagos, Nigeria. Journal of Environmental Chemistry and Ecotoxicology, 8(3):1424.

OLIVIERM., M.HOLLSTEIN, AND P.HAINAUT. 2003. TP53 Mutations in Human Cancers: Origins, Consequences, and Clinical Use. Cold Spring Harb Perspect Biol, 2(1): 1001-1008.

RELYEA, R. AND J. HOVERMAN. 2006. Assessing the ecology in ecotoxicology: a review and synthesis in freshwater systems, 10: 1157-1171.

SHARMA, P. AND R. S.DUBEY. 2010. Protein synthesis by plants under stressful conditions. Handbook of Plant and Crop Stress, Edition: 3rd Edition, Revised and Expanded, Chapter: Protein Synthesis by Plants under Stressful Conditions, Publisher: CRC Press, Taylor \& Francis Publishing Company, Florida.

TANG, J., N. ABOVICH, M.L. FLEMING, B. SERAPHIN ANDM. ROSBASH. 1997. Identification and characterization of a yeast homolog of U1 snRNP-specific protein C. EMBO J 16(13):4082-91. 
TARFIEI, A., H. ESLAMI, A.E. ASGHAR. 2018. Pharmaceutical Pollution in the Environment and Health Hazards. Journal of Environmental Health and Health and Sustainable Development, 3 (2): 492- 495.

TEISSEIRE, H., M. COUDERCHET AND G. VERNET. 1999. Toxic responses and catalase activity of Lemna minor L. Exposed to folpet, cop-per, and their combination. Ecotoxicol Environ Saf. 40(3):194-200.

Thrupp, T. J. 2016. Effects of pharmaceutical pollutants and their mixtures on aquatic organisms with particular focus on reproduction and endocrine function in a fish model species. Thesis Submitted for the Degree of Doctor of Philosophy, Brunel University, London: 1388.
WELLBURN, A. R. 1994. The Spectral Determination of chlorophylls a and b, as well as Total Carotenoids, using various solvents with spectrophotometers of Different Resolution. Journal of Plant Physiology, 144 (3):307-313.

WONG, P.K. 2000. Effects of 2,4-D, glyphosate and paraquat on growth, photosynthesis and chlorophyll-a synthesis of Scenedesmus quadricauda Berb 614. Chemosphere, 41:177-82.

ZHANG, Y., J. GUO, T.YAO, Y. ZHANG, X. ZHOU AND H. CHU. 2019. The influence of four pharmaceuticals on Chlorellapyrenoidosa culture. Scientific RepoRts, 9:1624.

\section{آثار ثلاثة منتجات صيدلانية شائعة الاستخدام على المعايير البيوكيميائية للطحالب الاقيقة \\ Pseudokirchneriella subcapitata (تحث ظروف المختبر)}

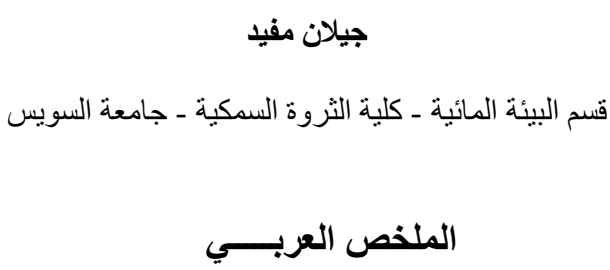

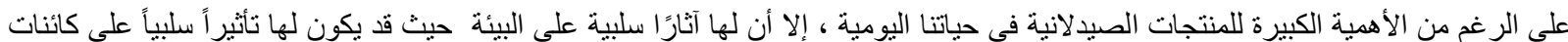

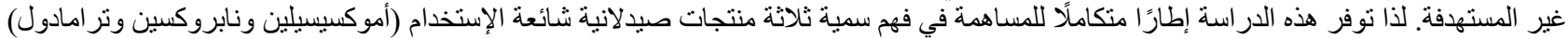

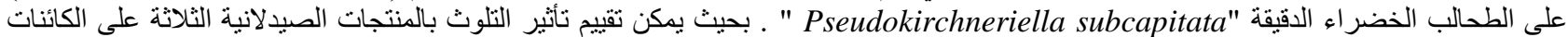

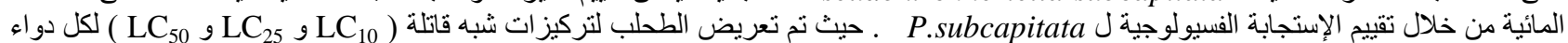

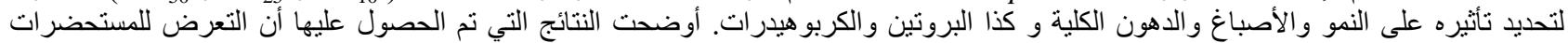

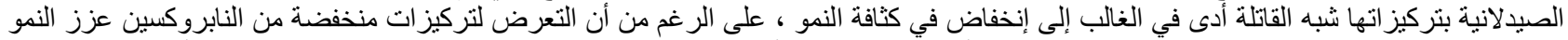

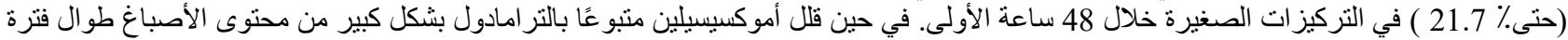

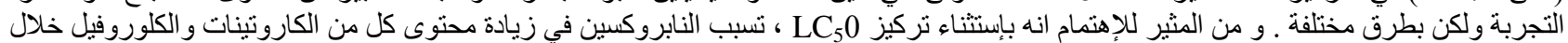

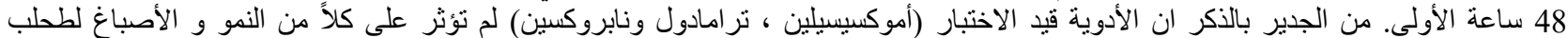

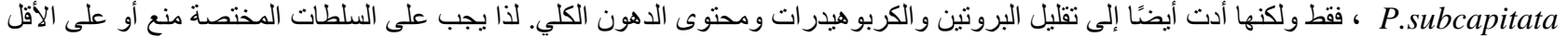

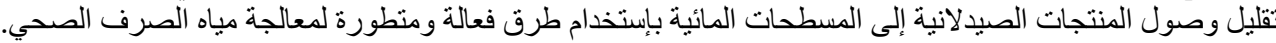

